\title{
EL PERIODISMO FINISECULAR DE RAMIRO DE MAEZTU
}

\author{
RAFAel Alarcón Sierra \\ ralarcon@ujaen.es \\ Universidad de Jaén
}

\begin{abstract}
Resumen
El presente artículo analiza la crónica y el periodismo finisecular antes de centrarse en el caso de Ramiro de Maeztu, del que estudia su práctica y concepto del periodismo, el análisis que en sus artículos hace de la situación española tras el «desastre», sus propuestas de «regeneración» y su crítica economicista del Estado y la Iglesia. También analiza su posición frente al anarquismo y sus puntos de contacto con Nietzsche (creación de una ética, un estilo y una máscara textual). Antecede a las conclusiones el estudio de su papel como crítico literario y artístico en las polémicas del modernismo.
\end{abstract}

Palabras clave: Ramiro de Maeztu, periodismo, crónica, fin de siglo, modernismo.

\begin{abstract}
This paper analyses chronicle and journalism at the turn of the century before focusing in Ramiro de Maetzu and studying his practice and conception of journalism, the analysis of the Spanish situation after the «Disaster» in his articles, his proposals for «regeneration» and his economistic criticism of State and Church. It also examines his position in relation to anarchism and his points of contact with Nietzsche (the creation of an ethics, a style and a textual mask). Before drawing conclusions, the article studies his role as literary and art critic of the Modernism's controversies.
\end{abstract}

Keywords: Ramiro de Maeztu, journalism, chronicle, turn-of-the-century, Modernism.

Anales, 26, 2014, pp. 11-41

DOI: 10.14198/ALEUA.2014.26.01 


\section{La crónica y el periodismo finisecular}

Aparte de algunas conferencias y folletos, Ramiro de Maeztu publicó pocos libros a lo largo de su vida, y cuando lo hizo fue, generalmente, reelaborando escritos aparecidos en diversas publicaciones. Su dedicación casi exclusiva fue el periodismo, al que consagró cientos de artículos y crónicas, diseminados en la prensa española e hispanoamericana (vid. Fox 1974 y 1988, Palacios 1983, Fernández, 1990). Fue el publicista que con más ímpetu y fortuna se dedicó a denunciar el fracaso de la Restauración en todos los aspectos de la vida española, y uno de los primeros periodistas profesionales en el sentido moderno de la palabra. Maeztu, designado a sí mismo como «el periodista» o «el cronista», formará parte de varias redacciones, reflexionando en voz alta acerca de la realidad política, exponiendo sus ideas y su visión del presente, creando una opinión pública sobre los hechos diarios. Su creciente prestigio intelectual como hombre de letras independiente y honesto fue posible gracias al desarrollo en España de un nuevo periodismo industrial.

Si la crónica periodística fue el molde primero donde se forjó la prosa finisecular, y uno de los lugares privilegiados para explorar la modernidad, ello fue consecuencia de la profesionalización de la escritura, del desarrollo urbano y de la consolidación industrial de la prensa periódica, proceso creciente durante todo el siglo XIX. La paulatina evolución del periodismo político y de partido hacia el informativo y literario, que debía entretener al lector de una naciente cultura de masas, propició el nacimiento de la crónica y la aparición de escritores como Maeztu. El tránsito desde la anónima sección periodística de los faits divers, noticias breves sin orden ni ilación, cada vez más numerosas, que se producen en la ciudad, hacia el nuevo molde de la crónica, supone la creación de un yo -a menudo sobre la marcha- que organice el caos de las informaciones heterogéneas y fugaces en un nuevo montaje, y les confiera un sentido revelador para aquellos lectores que a menudo ya las conocen (Alarcón, 2000: 14-31). En este sentido, la crónica se eleva a la categoría de género periodístico mediante el comentario personal de los sucesos que cotidianamente ocurren en la gran ciudad. Esta idea era reconocida por los primeros críticos que en España trataron de definir la crónica; así lo hace Gómez de Baquero (1905: 272-273) al escribir que «Su principal cualidad es el ingenio; su tipo el de una conversación escrita. Es el arte de la conversación aplicado a la comunicación con mil lectores por mediación de una hoja impresa».

En la era de la reproducción mecánica, el escritor finisecular muestra una postura ambivalente -dependencia y rechazo- ante el poder en aumento del periódico, medio a menudo indispensable para ganarse la vida, pero que en aparencia echa a un lado al hombre de letras: «el maquinismo, el factory system 
de los diarios modernos, parece reducir al escritor a vil aditamento del aparato telegráfico o a relleno miserable de los borceguíes del reportero» (Maeztu, 1997: 154). Como institución mediadora entre el sistema de producción, la sociedad y la escritura, el diario vampiriza al verdadero creador, lo convierte en un gris gacetillero que pierde su «aureola» y la exclusividad de su oficio, y debe adaptarse al aceleramiento de la naciente «cultura de masas», según anota Maeztu -adelantándose a Benjamin- en Hacia otra España:

Los verdaderos hombres de letras que se sientan en la mesa del café murmuran de la prensa. Tienen motivos particulares para odiarla. En esta labor del periodismo la belleza serena de la obra de arte no es posible. Se escribe con la cal y la arena del lugar común y de la frase hecha. El mármol y el granito literarios se agotaron con los clásicos. Hoy la cuestión estriba en fabricar mucho. Y a la gente de talento cuéstale gran esfuerzo resignarse a hacer del pensamiento una máquina de emborronar cuartillas.

Los que me rodean no se resignan, pero se limitan a protestar en voz baja y a dejarse oscurecer por el reportero (Maeztu, 1997: 60; cf. la «Pérdida de aureola» en Baudelaire, 1969, y Benjamin, 1973: 15-17).

La interpretación del periodismo como una de las causas de la crisis de la literatura es un tópico que repiten sistemáticamente los jóvenes modernistas a ambos lados del Atlántico (Darío, 1950: 121-125). Este sentimiento de crisis corresponde a una reorganización tanto de los medios de comunicación social como del campo literario; pero la queja de los nuevos escritores también responde a su tentativa de lograr un espacio propio. La cultura es parte de la industria moderna, y el escritor debe poner a la venta sus ideas en el mercado si quiere que estas lleguen al ámbito público. De este modo, a la vez que critica orgulloso el periódico, el escritor hace de la necesidad virtud y utiliza esta tribuna no sólo como un medio de subsistencia, sino como una forma de incorporarse profesionalmente a la actividad literaria y de implicarse de forma activa en su tiempo y su sociedad; de fundar un nuevo lugar de enunciación; de analizar los hechos según su exclusivo punto de vista y de exponer sus ideas; de conformar un público a la medida de sus necesidades, receptivo a su nueva forma de escritura; y, por último, de consolidarse como escritor y conseguir legitimidad en el campo social y literario. Así lo detecta claramente Maeztu en un diagnóstico sociológico cercano a George Simmel, donde fundamenta el papel hegemónico del nuevo escritor finisecular -el suyo propioy su ascendente intelectual sobre las masas y sobre la prensa como intérprete cualificado de la dinámica realidad:

Esa misma intensificación de la vida moderna, que hizo al público apartarse de los periódicos doctrinarios y preferir aquellos otros que le enteraran de cuanto ocurriera de notable, le llevó a demandarles el comentario de los 
hechos y la previsión de sus consecuencias. En efecto, no obstante, el espíritu nivelador de las muchedumbres, no tardó en echar de ver el público, que el comentario no brota espontáneamente, sino en muy pocos casos, a la simple lectura de la noticia. Es necesario especular sobre ella, conocer sus antecedentes, estudiarla con madurez, abstraerse, pensar, dedicarse únicamente a la investigación de las concausas que unen entre sí a las noticias de una índole dada. No tardaron en advertir las multitudes que el comentario del escritor profesional era y debía ser más acertado y de mayor alcance que el suyo propio (Maeztu, 1997: 154; cf. Simmel, 1986: 247).

Este «comentario del escritor profesional» es lo que da lugar a la crónica, género nuevo con dos rasgos bien reconocibles: ser una breve e instantánea reflexión sobre hechos inmediatos -el diario impone las limitaciones de tiempo y espacio- desde el punto de vista de una original conciencia creadora, que aprovecha los fugaces temas de actualidad para escribir libremente de lo que en realidad le interesa. Estas dos características significan otro aspecto más definitorio y revelador: la crónica es un ejercicio enfático de derivación y sobreescritura. Como apunta Mainar (1906: 187-188 y 193), «La crónica es comentario y es información: la crónica es la referencia de un hecho en relación con muchas ideas; es la información comentada y es el comento como información», de forma que «en la crónica el comentar se reduce a informar, en cierta manera, sobre el comentario». El escritor incide en asuntos y noticias previamente conocidos y ya publicados en el periódico. Ello es lo que hace posible que este género periodístico adquiera categoría, porque lo que predomina en él ya no es la información, sino una reflexión de lo ya conocido bajo un nuevo punto de vista. Y esto se consigue ofreciendo un trabajo verbal e intelectual que su materia prima, la simple noticia, no tiene.

De este modo, el periodismo, para el escritor, constituirá una auténtica gimnasia del estilo, como escribe Darío. Ya Gómez de Baquero (1905: 270), avisaba de que «La crónica parece, y es sin duda, un género muy personal; pero lo es en la forma, en la manera de tratar los asuntos más que en el pensamiento», y Mainar (1906: 188 y 193) advertía que la crónica nace de «cuidar la noticia» mediante «una presentación agradable», «darle forma literaria, hacerla interesante y sugestiva». El estilo -concepto clave para los escritores finiseculares- será lo que conforme y dote de unidad a la crónica, y la vía para que el periodista se sienta un auténtico creador. Paradójicamente, el prosaico y «antiestético» diario se convertirá en un inadvertido aliado del escritor, quien gracias a él moldeará una prosa verdaderamente moderna, ágil, flexible, fluida y seductora. En ella, los rápidos cambios de tono y de ritmo, el refinamiento de matices y sensaciones, los distintos estados de ánimo, lo llamativo y lo insólito, el humor y la ironía, lo trascendente y lo mundano, lo frívolo y lo 
agudo, lo formal y lo informal, lo cuidado y lo espontáneo, y todos los recursos imaginables de forma y estilo, encuentran su campo de experimentación y su lugar adecuado.

El periódico, por tanto, para Maeztu y sus compañeros finiseculares, no sólo fue un medio de vida y un propagador de la nueva literatura, sino uno de los factores que impulsaron al escritor a crear el nuevo lenguaje de la metrópoli, con toda la libertad que supone escribir en lo que se cree un género menor y efímero, tratando, por ende, aspectos de la realidad urbana hasta ese momento marginados de la representación literaria. Nunca se insistirá bastante en el papel que tuvo la prensa para la formación de una expresión adaptada a las realidades de la dinámica vida moderna, como bien señala Unamuno (1958, VI: 467):

El periódico debe parecer escrito en la calle, entre el estrépito de los carruajes, las voces de los vendedores ambulantes y el ir y venir de los transeúntes, en el lenguaje suelto y hasta descuidado de que éstos se sirven. ¡Fecundo descuido el de tal lenguaje! / [...]

El que, atado al duro potro de una redacción, tiene que tener al público, a diario, hablándole hoy de arte, mañana de hacienda y de guerra pasado mañana, no dispone, afortunadamente, de tiempo para pulir sus escritos, limpiándolos de galicismos y otras bagatelas. Escribe como buenamente se le ocurren las cosas; el lenguaje de sus trabajos es el lenguaje interior de su pensamiento mismo. [...]

Es el único modo de que aquí se hagan escritores, gentes que escriban en la lengua de la conversación y no en la de la oratoria.

Maeztu (1899h) postulaba una literatura «que fuera acción, látigo e impulso», a la vez que, hostigando a Clarín, pedía libertad para «romper la métrica y ajustar una nueva a nuevos ritmos; dividir el cervantesco párrafo; arrojar del diccionario a los maestros Ciruelo; ensanchar el idioma y el alma» (1899q), puesto que sólo se podrá construir una lengua verdaderamente moderna «despedazando el diccionario y echando la gramática a los perros» (1899p). Su estilo tendrá todas estas características: claro y preciso a la vez que vigoroso, intenso y enfático, siempre como reflejo de su personalidad e ideas, y en función de sus intereses intelectuales.

La propia novedad y flexibilidad de un género en formación hace que este no tenga unas fronteras definidas, y así se entremezcla y confunde con cualquier forma ensayística, el artículo periodístico, la noticia y el suceso, la entrevista y el reportaje, la crítica, la revista y la reseña, la semblanza y el retrato, las impresiones y el apunte, la estampa y la evocación, el relato y el fragmento lírico, la prosa poética e incluso el poema en prosa. De este modo encontraremos la crónica noticiera, la crónica reportaje, la crónica de viajes, 
la crónica-cuento o la crónica literaria, entre otros posibles tipos (Alonso, 1998: 220). Su indeterminación resulta manifiesta en uno de los primeros intentos por definirla en España, el que lleva a cabo uno de los principales cronistas de entresiglos, Enrique Gómez Carrillo (1902):

¿Qué es la crónica?

Este dice:

-Es una sonrisa en la prosa diaria del periodismo.

Aquél asegura que es la conciencia de la actualidad social.

El otro murmura:

-Es el libro de memorias sentimentales de nuestra época.

En realidad, es esto y es más, puesto que es todo. [...]

Los noveladores, los poetas, los filósofos, los publicistas, se especializan cada día más. Los cronistas no, porque son de consuno noveladores y poetas,

filósofos y publicistas, psicólogos y artistas. El universo entero les pertenece.

La crónica ofrecerá un escaparate de la vida moderna, producido por un escritor que quiere ser moderno a toda costa. Se manifestará como el género propicio para explorar las cada vez más rápidas transformaciones de la realidad, gracias a su procedencia periodística y urbana. En este sentido, aunque la chronique como tal surgiera en la prensa parisiense de mediados del siglo XIX, los antecedentes inmediatos del nuevo género se remontan al artículo de costumbres, que ya poseía el mismo doble origen del que hace gala la crónica.

Ambos géneros comparten su propósito de revelar aquellos aspectos de la vida cotidiana de los que no se ocupa la Historia con mayúsculas, sobre todo los de las clases medias de la sociedad urbana, con unos procedimientos similares: la mezcla de lo objetivo con lo personal, de la descripción directa con la propia reflexión, creando un impertinente «mirón», espectador u observador que recorre a su antojo el teatro de la ciudad -retórica del paseo y del viaje-y anota cuanto ve, primero sin involucrarse y luego como su protagonista principal. Este sujeto perderá de forma progresiva su apariencia de neutralidad en la visión y en la escritura a favor de un yo cada vez más crítico y preponderante, y de un estilo cada vez más marcado, como sucede en la crónica finisecular y en Maeztu. Ambos géneros son conformados según las limitaciones propias del periódico: la concisión, por un lado, y el tratamiento de temas actuales ya conocidos por el lector, pero con una perspectiva inédita y un estilo revelador. La fugacidad -temporal, espacial y temática- y su consecuencia, el necesario fragmentarismo de lo tratado, unidas por una necesaria conciencia seleccionadora, son las condiciones que se acentuarán en la crónica periodística y que determinarán su triunfo. Sin embargo, muchos de los temas del artículo de costumbres seguirán perdurando en la crónica, como puedan ser las continuas transformaciones de la ciudad, los ámbitos urbanos de socialización-del 
café al teatro-, las distintas festividades, y su tono crítico, humorístico o satírico, así como su enfoque dialéctico, la frecuente apelación a un interlocutor, a veces de forma epistolar.

\section{El periodismo y la ciudad}

Tanto el periódico como la crónica son productos netamente dependientes de la ciudad; es más: se constituyen mediante la segmentación temporal y espacial propia del mundo moderno. En su contacto diario con lo cotidiano, la crónica supone la recreación verbal de la nueva experiencia urbana, tanto de las ansiadas metrópolis modernas a las que el escritor se desplaza en calidad de guía especializado, como de las ciudades en vías de modernización, e incluso de las viejas «ciudades muertas».

La ciudad no es sólo el contexto o el escenario donde nace la crónica, sino el mismo campo de la significación, donde aquélla adquiere sentido. A la vez, de forma inversa, la crónica dota de lógica al espacio urbano al recomponerlo y contarlo a sus habitantes: la crónica es el nuevo lugar de representación de la ciudad. Ciudad y crónica crecen a la vez, y ambas representan la fragmentación del sentido, de los sistemas, discursos y códigos, distintiva de la modernidad. De este modo, como ya hiciera en menor escala el costumbrismo, la crónica reinventa la ciudad, cree dominarla al describirla, en un momento en que ésta desarticula la forma y la memoria de sí misma por efecto de su rápido crecimiento y del incipiente «caos en movimiento» que provoca el moderno tráfico urbano de coches y transeúntes.

Baudelaire, en el prólogo a Spleen de Paris, asegura que es esta experiencia urbana la que impone una nueva forma de escritura. Este otro modo de escribir, si bien afecta a todos los géneros, se quintaesencia en la crónica periodística, que muestra de preferencia ese otro modo de vivir. Y si el cronista experimenta a trechos la gran ciudad tanto al transitar por ella como al escribirla, el ciudadano, además, la experimenta al leerla en la crónica; de hecho, esta es frecuentemente interpretada como un bocado de realidad, "porque es reflejo del vivir, instantánea de la vida» (Mainar 1906: 188), y supone «auscultar un poco el corazón de la vida»-de los demás y de uno mismo- (Machado, 1923).

La escritura del Maeztu finisecular se construye necesariamente con los nervios y el dinamismo de la moderna ciudad, de la que es entusiasta partidario: «la belleza de las calles rectas, y de la fábrica, y de la máquina, y de la Bolsa», que «representa la eterna hermosura del movimiento» (1997: 173). Una nueva escritura y una nueva España, acomodadas al necesario progreso industrial y tecnológico, son sus objetivos paralelos, puesto que el desarrollo económico trae también consigo la riqueza cultural: «podemos considerar la 
red ferroviaria y el hormigueo de fábricas como un pedestal sobre el que se yerga una generación de artistas. Sobre las cimas de las chimeneas vibrará la lira del poeta y vibrará desde lo alto...» (1997: 91).

Si el periódico se organiza gráficamente a imagen y semejanza de la ciudad, a la vez que privatiza la comunicación social, en su interior la crónica representa el simulacro de un tradicional espacio público de ocio y encuentro. De ahí, en parte, la apariencia de oralidad, de conversación o diálogo informal, que el cronista sostiene con sus interlocutores, apelando a un lector cómplice o interpelándolo con ironía, procedimiento tan frecuente en Maeztu. En definitiva, incluyendo al otro y a su respuesta en su tribuna, al modo de una comunidad de amigos, en contraste con la más real anonimia de las multitudes urbanas en movimiento. La crónica reinventa, además, el pasado de la ciudad, une el pasado con el presente, lo nuevo con la tradición de la misma, lo antiguo con lo moderno, es una memoria de todo aquello que desaparece por la fuerza de la modernización, como ya se proponía el artículo de costumbres. El cronista trata de unir o articular aquello que la modernización destruye con las novedades que procura.

La retórica del paseo es un modo fragmentario de experimentar la ciudad, alternativo a la convencional mirada totalizadora y omnisciente, que ya no se puede mantener en las heterogéneas urbes modernas. Al caminar indolentemente, el flâneur traza un itinerario y un discurso que establece un orden -arbitrario pero tan válido como cualquier otro- en el espacio, el tiempo y los acontecimientos desarticulados de la ciudad. A su vez, el paseo o «flanería» es una nueva institución cultural en la que un voyeur observa la ciudad como un objeto en exhibición, un espectáculo que se experimenta, se representa y se cuenta a los demás -Baudelaire, 1969: 138: «Quelles bizarreries no trouvet-on pas dans une grande ville, quand on sait se promener et regarder?». Ello explica que Gómez de Baquero (1905: 273), escribiera que la vanidad del cronista era «la del intelectual que se figura que el mundo y los hombres han sido hechos para que él se recree o de algún modo se emocione con su contemplación; y que los sucesos ocurren para que él los saque punta». Pero de este modo el cronista desactiva la sensación de caos y el peligro de la gran ciudad al transformarlo en un espacio aparentemente conocido y familiar. En última instancia, cada crónica no es tanto una pieza referencial de un puzzle que acabaría conformando la ciudad como un imaginativo relato de ordenada ficción sobre la misma. De ahí también el entrecruzamiento de crónica y cuento en la literatura finisecular. 


\section{El periodismo según Maeztu}

En Maeztu encontramos todas las características del moderno cronista que he citado, pero con una voluntad confesional y un espíritu crítico y combativo exacerbados, que busca el contacto directo con el lector, apelándolo y reflejándolo, en una relación dialéctica establecida a través de un estilo vehemente y torrencial, musculoso y eléctrico, tan pronto espontáneo como reflexivo, contradictorio como programático. La presencia autobiográfica en sus textos es constante: Maeztu no sólo es el yo narrador, testigo o protagonista que transforma estética e ideológicamente la materia de la que escribe, sino que se vierte en ellos como un yo múltiple, enfático y vivencial. No en vano, en su «Autobiografía» publicada en Alma Española (1904), se representa como una no-identidad capaz de asumir todas las contradicciones, contrafigura palmaria del diderotiano neveau de Rameau: «pensaréis que Maeztu es un filósofo o un buscavidas; un héroe o un ignorante; un poeta o un charlatán; un anarquista o un jesuita, o cualquier otra cosa [...] la solución de estas antítesis y tesis es la que da el protagonista; Maeztu no existe; es una boya desamarrada que flota en todos los mares».

Sin embargo, pese a estas paradojas de realización egocéntrica, en su papel de publicista y abanderado de la renovación social y política de su país -de la regeneración, en palabra de la época-, su influencia intelectual estará a la altura de Unamuno y Ortega y Gasset, con quienes intercambiaría a menudo ideas y puntos de vista en encendidas polémicas periodísticas. En los años finiseculares, Maeztu denunció con intensidad y perseverancia el fracaso de la Restauración en todos los niveles de la vida nacional. Pero, además, desde las páginas de la prensa diaria propuso un inusitado programa de alternativas desde una óptica peculiar, mitad socialista y mitad nietzscheana, mezclando lucha de clases y pensamiento aristocrático. Maeztu combinaba así la interpretación dialéctica de la historia en términos de praxis económica y la creencia en la fuerza individualista de la voluntad y la energía, encarnadas en el hombre de acción, el self made man capitalista. Este formaría la elite minoritaria capaz de transformar el paisaje estéril de la meseta española en un moderno entramado industrial, al margen del Estado y de una política caduca.

El papel del periodista era el de facilitar este proceso denunciando la situación, mentalizando a sus lectores y promocionando las soluciones para movilizar a la opinión pública. Según afirmaba en «Juventud menguante» (1904), «hacer de la pluma un instrumento de alcance y de eficacia». Maeztu entiende de este modo su función de escritor en la nueva prensa de masas. Desde su punto de vista, la misión del periodismo consiste en educar cívica y políticamente al pueblo, analizando de forma crítica los acontecimientos 
trascendentes para el futuro de la colectividad. El periodismo es el sistema nervioso de las sociedades modernas, y actúa como un divulgador del programa de las minorías intelectuales, como correa de transmisión entre los dirigentes y la sociedad: «Creo que los periodistas españoles no hemos reparado en que a la prensa corresponde, si no la dirección suprema de los pueblos, función de los creadores de ideas, de los intelectuales puros, abstractos, andróginos, al menos la orientación inmediata de la vida colectiva, mediante la transformación de los productos ideológicos del intelectualismo en ideales eficientes, carne y sangre de un pueblo» (1997: 96), visión que repetiría en varias ocasiones (1966: 73-79). En esta interpretación, así como en el aprecio hacia las elites directoras, hay más de un paralelismo con las ideas que desarrollará Ortega.

¿Cómo se lleva a cabo este ideal, a la vez pedagógico y reformador? Maeztu en sus crónicas y artículos no teoriza dogmáticamente en el vacío, sino que denuncia casos concretos, elabora sus análisis partiendo de los problemas de la actualidad cotidiana que atraen la atención pública, para a continuación proponer soluciones con voluntad de concienciar y crear un clima de opinión favorable. De esta forma, demuestra conocer muy bien los mecanismos de la prensa moderna y de sus lectores desde el principio: «pocos artículos socialistas se han escrito con el propósito de hablar al corazón y a la cabeza del obrero, amoldándonos a su inteligencia, ayuna de cultura, y dando expresión a sus aspiraciones íntimas, esas expresiones que el obrero no ha sabido aún formularse con entera claridad [...] hagamos lo posible por llamar al pan pan $\mathrm{y}$ al vino vino, $\mathrm{y}$ dejarnos un poco de disquisiciones doctrinarias para ocuparnos algo más de la carne, de la casa y del salario del obrero» (1897).

\section{La crítica de la prensa desde la prensa}

Este conocimiento profundo del periodismo lo manifestó no sólo en una dedicación absorbente, casi exclusiva -en una época en que todo escritor recalaba forzosamente algún tiempo en él- que le llevó a practicar todas sus formas y géneros, de la crónica al reportaje, sino en una sostenida reflexión teórica sobre sus principios y función, que no excluyó una crítica sistemática de la prensa contemporánea. El punto de partida de su análisis fue el alejamiento de la prensa y el país que se produjo a raíz de la derrota frente a los Estados Unidos, producido por supeditar la realidad de la situación a un infundado y demagógico triunfalismo patriotero. El periodismo nacional no estuvo a la altura de las circunstancias, en lo cual mostró el anquilosamiento y la misma falta de modernización que el resto de las estructuras sociales del país. Tres hechos quedaban al descubierto: su insuficiencia técnica y humana, su dependencia 
política y su incapacidad para tomar el pulso a la realidad de la compleja vida moderna, paradójicamente frente a su inmenso y creciente poder social.

Maeztu pronto denunció, entre «los secretos de la crisis», los relacionados con los diarios: «El de la publicación de unos periódicos cuya vida ha de ser un compendio de todos los azares del hampa moderna [...] El de la gran penuria de la prensa española, penuria de ideas, de escritores, de público. El de nuestros periodistas, condenados a hacer política menuda, aunque se queden sin lectores. El de la parálisis nacional, porque su sistema nervioso -la prensa- sólo se agita por cuestiones de personas, que ha de falsear, exagerándolas, para que aparezcan como problemas colectivos. El de la sistemática ocultación de la verdad, porque del cultivo de la mentira política depende la existencia común» (1899g).

Al desfase entre los hechos y lo publicado se unía la «atrofia intelectual de la opinión», tanto causa como efecto de lo anterior, puesto que «El público español busca en los diarios un confesor que le absuelva sin penitencias y que cultive sus prejuicios, respetando prudentemente su letargo intelectual» (1899g). De este modo, la prensa es incapaz de detectar los asuntos de verdadera relevancia social: «Nuestra prensa es así. Comenta el motín, la batalla, el discurso, el personaje; vive de apariencias; lo substancial de la vida española pasa por sus narices y ni siquiera lo vislumbra» (1899p).

Bien es cierto que estas críticas contra «los periódicos vacíos de ideas y repletos de frases hechas» (1997: 63) no eran desinteresadas, y a la parte de verdad que tenían hay que unir el deseo de Maeztu de legitimar su papel intelectual y de conquistar un espacio -cuanto mayor, mejor- en el mismo centro del nuevo campo literario y social que él mismo estaba configurando al dinamitar el preexistente.

Todo ello le llevó a realizar un completo análisis del fenómeno en Hacia otra España. Allí sintetizó la rápida transformación del periodismo: desde la publicación doctrinaria y familiar, dependiente del político de turno, al moderno diario informativo industrial de grandes tiradas. La reconversión del periódico en una empresa moderna y en un medio de gran influencia social impone una nueva profesionalización: «no ha hecho el maquinismo periodístico más que decuplicar los deberes y responsabilidades del escritor, al implantar el sistema de 'Gobierno por la prensa', que ha sustituido virtualmente a la utópica 'soberanía popular', en todas las naciones democráticas» (1997: 155). La prensa de masas ya ha adquirido la categoría de cuarto poder en los estados modernos, tal y como claramente percibe Maeztu: de ahí también su interés por ocupar en él una posición central. 
Sin embargo, «las cuestiones trascendentales [...] no alcanzan de los diarios de la corte ni los honores de una mediana información. No parece sino que la vida nacional les es completamente extraña» (1997: 159-160). Frente a ello, insiste en su concepción del papel pedagógico y transformador que les corresponde: «Fuera empeño meritorio de la prensa estudiar concienzudamente las causas de nuestro atraso industrial y de nuestra postración agrícola. Los periodistas despertarían poderosamente el espíritu de asociación en las clases productoras, educarían a nuestros hombres públicos, infundirían el amor al trabajo a una juventud educada en el parasitismo de los destinos» (1997: 158-159). Los modelos que propone son los europeos, como el ejemplo francés frente al problema de la educación, ausente en los periódicos de Madrid.

«¿Cómo se explica esta ceguera de los periodistas madrileños?», se pregunta. Y la respuesta es su interinidad, sus deficientes condiciones laborales, su escasa preparación - «De los 200 escritores que redactan los diarios madrileños, apenas hallaremos una docena que hayan hecho del periodismo su profesión definitiva»- y su dependencia de los partidos o gobiernos: «Desde el propietario de un periódico al último reportero, todo el pensamiento del personal de redacción gira siempre en derredor de la política» (1997: 161). Maeztu ya había caracterizado al frecuente ejemplar de periodista trepador con un desdén donde se descubre además su propia afirmación, así como su deseo de ascenso social: «el tipo que todos conocemos de sobra en el periódico; el redactor sin enjundia y sin estilo, despreciado intelectualmente por sus compañeros, que colando reclamos de prohombres, y frecuentando tertulias de copete, acaba en la gobernación de una provincia, mientras sus compañeros, los escritores de valía, a vuelta de una lucha penosa por conservar su independencia, andan solicitando credenciales de dos mil pesetas letra» (1997: 71).

Pero, pese a esta penosa situación, la moderna prensa de masas es capaz de aupar o deponer gobiernos, y de promover la paz o la guerra, como acababa de ocurrir. Los periódicos habían alimentado vanamente las esperanzas de la nación en la victoria militar, e incluso su demagogia propagandística había precipitado el enfrentamiento bélico, en un delirio que «alcanza a todos» (1997: 60). Los diarios habían creado tal estado de opinión que la respuesta del gobierno y el ejército debía adecuarse a estas ilusorias expectativas: «La prensa madrileña nos lanzó a la guerra con los Estados Unidos, o cuando menos no hizo nada para evitarla» (1997: 162). Ambos quedaron en evidencia al mismo tiempo: «iTodo el progreso de este siglo ha servido para entregar el destino de las naciones a aventureros de la política y la prensa, cuyo juicio 
está falseado constantemente por la excitación artificial en que viven!» (1997: 119).

Por eso, razona Maeztu que su mayor delito no consistió «en haberse equivocado al juzgar belicosa a la nación sino en un absoluto incumplimiento de algunos de sus deberes, especialmente del deber de información» (1997: 155156). Los corresponsales enviados a Cuba y Filipinas fueron «incapaces de formarse opinión, sobre ningún asunto de alguna trascendencia»o bien se dedicaron a "prepararse una posición fuera del periodismo». Sin embargo, «ante el derroche infructuoso de miles de vidas y cientos de millones», en ningún momento se detuvieron «a fin de preguntarse si valdrían las colonias la ruina y despoblación de la metrópoli» (1997: 156).

La interpretación razonada, objetiva y orientadora acerca de los hechos ocurridos ha brillado por su ausencia: «por ninguna parte hemos leído esos informes minuciosos, imparciales, escrupulosos, dignos, con que los grandes diarios de otros pueblos suelen ilustrar a sus lectores» (1997: 141-142). Por tanto, la culpabilidad por el desastre también alcanza a los medios escritos, en una retórica y flagelante primera persona del plural: «Sí, señores periodistas, en lugar de estudiar seriamente la causa de las guerras coloniales y sus remedios menos costosos, como era nuestro deber, nos hemos salido con el repertorio de las frases sonoras: ¡integridad, más soldados, más empréstitos, derramemos hasta la última gota de sangre!... Eso era más cómodo que pensar maduramente, sobre todo para decirlo desde la sala de una redacción. Pero, ¿no alcanza alguna de esas responsabilidades de que hablan los periódicos a los periódicos mismos, que han engañado al pueblo al tomarle la medida de sus fuerzas?» (1997: 141).

La autocrítica se impone. El interés de Maeztu por hacer de la prensa en España un contrapoder al caduco sistema político de la Restauración y un dinámico agente de transformación social resulta claro: «La prensa debió suplir con informaciones concienzudas, la ignorancia de nuestras clases gobernantes», pero «No lo hicimos los escritores españoles a su debido tiempo»; por tanto, «No tenemos derecho a hurtar el cuerpo a las censuras. Acaso al afrontarlas hallemos una recompensa a nuestra sinceridad; la de procurar hacernos dignos del elevado puesto en que nos coloca la intensificación de la vida colectiva moderna» (1997: 96), palabras finales que recuerdan de nuevo el diagnóstico de Simmel.

La realidad es que «los periódicos no dejan de advertir que la nación se les ha escapado entre las manos» (1997: 162). Ya no es solo un problema de adecuación informativa. Los diarios también vertebran la imagen y la cohesión de un país, como señala Maeztu: «la prensa debe desempeñar, respecto 
de la nación, el papel de los sentidos respecto de los individuos». El gran peligro es que «España no vive de otra vida afectiva nacional que la que percibe diariamente por conducto de la prensa»y, por tanto, «la muerte del periódico madrileño es la muerte del espíritu nacional» (1997: 160). Por eso, advierte de la necesidad de «rehacer su crédito» para que «no lleguen tarde todas las soluciones», creando «un poderoso lazo espiritual entre los distintos elementos nacionales». Su reconstitución debe hacerse «con elementos nuevos», es decir, con «elementos completamente ajenos a los partidos presentes y futuros», o si no, nuestro periodismo «morirá con lo viejo» (1997: 165).

Maeztu demuestra en su análisis comprender el peso político y social que tiene la prensa en las sociedades modernas, y por ello enfatiza su interés en que esta tome una dirección correcta. Por ello margina los aspectos propios del periodismo industrial de grandes tiradas que no son útiles para sus objetivos, como el sensacionalismo y los asuntos intrascendentes, los cuales, paradójicamente, son frecuentes en la moderna crónica de entresiglos, que él contribuye tan poderosamente a crear.

\section{El «desastre» y la regeneración}

El mayor detonante para las propuestas de Maeztu fue el fracaso de la guerra colonial contra Estados Unidos en Cuba y Filipinas, y el estado de atonía en que se vio sumergida la nación tras «el desastre». Maeztu tuvo conocimiento directo del conflicto colonial en Cuba, y este es uno de sus temas prioritarios. Mientras que en la prensa española domina un patriotismo exaltado e irracional, Maeztu analiza de forma sociológica la situación, aun antes de la pérdida de las colonias, constatando la realidad de los hechos. En «¿Qué se debe hacer de Cuba?» (1897a) afirma que «se olvida que la revolución cubana, como todas las revoluciones, es un hecho eminentemente social» (Maeztu, 1977: 59). Ni la guerra sin reformas ni la autonomía son soluciones consistentes; el enfrentamiento es de la ciudad contra el campo, del comerciante contra el agricultor, debido a que los primeros explotan a los segundos. Con la guerra, el gobierno está despoblando España de trabajadores y aumenta la deuda nacional, con lo que se pone en peligro el progreso de la nación. Por lo tanto, lo más sensato sería olvidar la isla, abandonar la retórica imperial y quijotesca y dedicarse a industrializar el país.

Análisis similar repite en «La vara de medir» (Maeztu, 1997: 137-138). Su posición fue minoritaria en la opinión y la prensa española, aunque los hechos acabarían dándole la razón. La guerra fue popular, y Maeztu iba a recoger en los artículos de Hacia otra España la contradicción entre «la tendencia histórica, guerrera y heroica» y «la tendencia contemporánea, conservadora y

Anales, 26, 2014, pp. 11-41 
positivista» (Maeztu, 1997: 95). Refleja el fervor popular en el autobiográfico «La marcha del regimiento», pero también la visión de los soldados enfermos, inútiles o muertos, que regresan en los barcos («Una novela de Loti»), el «lúgubre desfile de muertos vivos» que devuelve América («Dolor que pasa», Maeztu, 1997: 145), el mercadeo de hombres para la guerra: «Quién se cambia por diez duros, quién por ciento, quién por mil. Fue problema de ofertas y demandas. Se cotizaba la carne para el vómito, como en la Lonja de Víveres de La Habana se cotizan los fardos de tasajo» (Maeztu, 1997: 107), o el tránsito de un momento a otro, con una invitación final al amotinamiento: «En la primera fase el pueblo hacía coro al entusiasmo militar»; «Hoy en día se agrupa en asambleas, aún no se niega a que sus hijos vayan a la guerra, pero un frenético anhelo de nivelación le sacude las vértebras, de su garganta brota un grito de dolor, que atraviesa las ciudades y aldeas [...] Mañana [...] pobres y ricos dirán [... 'A la guerra de Cuba ¡no vamos!'» (Maeztu, 1997: 108).

Todo lo ocurrido lo sintetiza de forma clara, con la misma óptica económica, $\tan$ lejana del florido retoricismo imperante -tanto el triunfal de los primeros momentos como el luego quejumbroso- y tan cercana a la posición del partido socialista, en un párrafo de «El separatismo peninsular y la hegemonía vasco-catalana»: «El deseo legítimo de aprovechar las colonias en favor de nuestras industrias, ha sido, durante largos años, el principal motivo de disgusto entre peninsulares y cubanos; ese legítimo deseo fue el causante del famoso movimiento económico de Cuba, preliminar importantísimo de la insurrección; ese deseo natural, incompatible con las aspiraciones de la industria norteamericana, ha dado origen a la última desastrosa campaña» (Maeztu, 1997: 189).

Pero antes del desastre ya propugnaba un profundo cambio en la realidad socioeconómica de «Este país de obispos gordos, de generales tontos, de políticos usureros, enredadores y 'analfabetos'» (Maeztu, 1997: 109), violento ataque con el que expresaba su rechazo de las estructuras decimonónicas, responsables de la parálisis nacional e incapaces de construir un estado moderno. Su voluntad y su escritura las pone al servicio de la regeneración de la patria, con una peligrosa concepción antisistema: hay que construir el país al margen de la política y el Estado, uniendo los esfuerzos de los intelectuales y los industriales, en una alianza nacionalista de hombres pragmáticos y superiores (proyecto sin duda bien intencionado, pero que suena a fascismo avant la lettre). En un momento en el que se creía en el triunfo de los anglosajones frente a la decadencia de los latinos, y el conflicto con los Estados Unidos había sido buena muestra de ello, más valía aprender la lección: «Si España presenta una resistencia invencible a la iniciada industrialización burguesa, 
nuestra nacionalidad será arrollada por extranjeras manos» (Maeztu, 1997: 51).

Su tono y sus soluciones se separan de las de la mayoría de la literatura regeneracionista surgida a raíz del desastre. A menudo las expresa en términos nietzscheanos, como una inversión de la tabla de valores: el empresario capitalista es el superhombre del futuro, y él, el Zaratustra que lo proclama; la nueva epopeya, la industrialización del país, y su héroe, el burgués emprendedor y adinerado (18991l). No comparte el general tono lastimero («...Diga lo que quiera el pesimismo, no moriremos de un hartazgo de dolor», Maeztu, 1997: 145), ni la tentativa de reconquistar o reformar la política: por eso, si en un principio simpatiza con el movimiento asambleísta de Costa, luego le decepciona su falta de consecuencia al proponer formar un nuevo partido. El nacionalismo de Maeztu es individualista y contrario al Estado: su ideología es la del darwinismo social, la iniciativa privada anglosajona y el nietzscheano hombre de acción, que logra el triunfo por su propia voluntad y energía, y no por la intervención y el apoyo estatal (vid. Blas Guerrero 1993 y Villacañas 1999).

Maeztu escribe en la prensa acerca de la realidad social y económica de España sin caer nunca en los determinismos filosóficos o culturales sobre el pasado de la patria, tan habituales en los diagnósticos regeneracionistas finiseculares, de Ganivet a Unamuno. Su posición es antihistórica; solo le preocupa el futuro de la nación, aunque es consciente de la alucinación de sus compatriotas por lo pretérito (Maeztu, 1997: 209). Tampoco sufre la mirada ensimismada de la mayoría de los escritores del momento, de Unamuno a Azorín o Baroja, hacia Castilla: Maeztu propone acabar con la meseta castellana generalizando el modelo industrial vasco y catalán en el interior de la península. Consecuentemente, su hábitat tampoco será la intemporal ciudad muerta del interior (Toledo o Granada), sino la moderna ciudad industrial, encarnada en el Bilbao de su primera juventud. Y su escritura, práctica y directa, alejada tanto de la plúmbea retórica decimonónica como del simbolismo decadente a la moda (aunque alguna vez se contagie de sus metáforas, recursos y motivos), corresponderá a este ecosistema, a sus necesidades de renovación y a la intensificación de la vida moderna que tiene lugar en él.

Frente a la visión nacionalista de Ganivet o Unamuno, Maeztu plantea una conquista de Castilla análoga a la del Oeste americano (no en vano, el valedor de la España intrahistórica lo acusará de yanquismo). Sus ideas al respecto las sintetiza en «La meseta castellana»: «La vida del litoral es imposible mientras el centro no se renueve y no progrese». Por ello propone la «colonización de Castilla». Los destinados a llevarla a cabo son los más preparados para ello: 
son los comerciantes catalanes y vascos quienes tienen que emprender la revolución económica de la meseta (Maeztu, 1899ñ y 1997: 191).

El periódico debe ser la plataforma para el cambio, si no se dedica a ser «eco exclusivamente de la vida ciudadana»-su contexto natural-y denuncia «la incesante despoblación y consecuente abandono de la tierra» a la que quizá haya contribuido con su olvido de la España agrícola en beneficio de la urbana. A este programa industrializador también deben aplicarse los nuevos escritores, en una clara andanada contra los esteticistas de su tiempo: «Para los intelectuales es esa colonización un nuevo ideal. No se le tache de prosaico y pobre. ¡Pobres de ánimo son los poetas que no acierten la epopeya del dividendo y del negocio, cuando es tan tentador el empeño de transformar nuestro romanticismo huero en práctico entusiasmo!...» (Maeztu, 1997: 171). Este, advierte, no es un ideal altruista; en línea con su óptica nietzscheana y económica, la industrialización se hará únicamente por egoísmo, espíritu de lucro y ambición de poder (Maeztu, 1997: 185).

\section{La crítica economicista al Estado y a la Iglesia}

La modernización de la meseta requiere que los hombres de negocios se sobrepongan a los poderes políticos. La crítica al Estado es en Maeztu una violenta posición antisistema basada tanto en sus ideas nietzcheanas como en la convicción de que aquel dedica los recursos financieros que deberían destinarse a la industrialización a una inútil clase media que vive a expensas del presupuesto: los funcionarios, el ejército y el clero, por no hablar del clientelismo creado por los partidos políticos de la Restauración. La solución es el «abaratamiento del Estado para desarrollar la riqueza pública» (1899c), puesto que «el pan del presupuesto no basta para mantener a tanta gente». La solución ha de ser radical, y en ella han de participar tanto los productores como los obreros (1899d).

Puesto que «España es un país por hacer», Maeztu repite su diagnóstico y su propuesta de limitar todo lo posible el intervencionismo estatal (1899f), porque la verdadera «Obra patriótica es la de intentar reducir el Estado» (1899n). Esta es la razón de su fe en la iniciativa individual: el Estado está anquilosado y es impotente para llevar a cabo una modernización; capta de forma inane los capitales y los hombres y no es capaz de crear nada: «Por donde quiera se nos aparece el parasitismo presupuestívoro, ahogando cuantas iniciativas de desarrollo brotan en el país, pesando sobre el lomo de las clases laboriosas» (Maeztu, 1997: 184). Por ello critica la confianza de Costa en los partidos políticos y proclama que «Sólo cuando las clases burguesas se hayan desembarazado del expedienteo, comenzará decididamente para España una 
tarea de labor eficiente» (Maeztu, 1997: 176). En esta posición también influye su conocimiento de la historia política y social de Inglaterra (Maeztu, 1900d; Santervás 1987).

De modo análogo, la primera motivación de su anticlericalismo también es economicista: la Iglesia absorbe de forma estéril el capital y su educación es inservible, porque no promociona la idea del enriquecimiento, el espíritu de lucro, no forma individuos ambiciosos, «hombres capaces de bastarse a sí mismos» que sepan «lo que el dinero vale y cuesta». Es una institución que, como el Estado, impide el desarrollo industrial del país (Maeztu, 1899a; vid. además 1899m y 1901a).

Maeztu exalta al hombre de negocios; considera que es el objetivo más útil de su labor como periodista: «Ya que siendo un contemplativo no puedo convertirme en un money maker (hacedor de dinero) haré lo posible para ser siquiera un money maker's maker (hacedor de hombres que hagan dinero). / ... No veo otro modo de cooperar eficazmente con la pluma en la obra de hacer patria» (18991l). Entonces, ¿dónde queda su socialismo? Maeztu es un socialista peculiar: está de acuerdo con su interpretación económica de la historia, y cree en él «por cuanto significa movimiento, acción, lucha, más que por su ideal de armonía y calma» (1899i). La lucha de clases la pasa por el filtro nietzscheano, y su fe en el individualismo, tan marcada por el filósofo alemán, hace imposible que se reconcilie con el objetivo final de la propiedad colectivizada. Maeztu apoya la voluntad y la energía tanto de los capitalistas como del movimiento obrero, porque del incremento de ambos depende la industrialización del país: el patrono cuida de sus operarios socialistas porque son los que mejor trabajan (1897b).

El problema es que en España no se ha desarrollado lo suficiente una burguesía emprendedora, por culpa del Estado, las oligarquías caciquiles, la Iglesia y el clientelismo político. En una concepción dialéctica de inspiración marxista, el aumento de las fuerzas productivas es necesario para la implantación del socialismo (vid. Blanco Aguinaga, 1970); pero el Maeztu de Hacia otra España no defiende la industrialización nacional primordialmente en beneficio del obrero; los elogios persistentes son para el capitalista emprendedor (vid. Abellán, 1973 y Zaratiegui, 2006), pronostica un socialismo integrado en el parlamento y el individualismo del superhombre nietzscheano (Maeztu, 1997: 177).

\section{Maeztu y el anarquismo}

Bajo esta misma óptica se entiende que Maeztu, a pesar de su crítica al Estado y a la política de la Restauración (y a pesar de Nietzsche), no estuviera de 
acuerdo con el anarquismo, a diferencia de otros escritores (Baroja o Azorín entre ellos) que se sintieron atraídos por un movimiento de gran fuerza social en el fin de siglo. La razón estaba clara: la agitación ácrata podía paralizar o dañar el desarrollo económico de la nación. Por el contrario, el socialismo era un movimiento obrero disciplinado y capaz de desarrollarse a la par que el necesario proceso de industrialización. Maeztu analiza el anarquismo en una serie de artículos. Tras reconocer su preponderancia social entre el proletariado y pasar revista a sus objetivos, la propaganda por el hecho y la huelga general, llega a la conclusión de que para erradicarlo hay que combatir la incultura del obrero y evitar la violencia gubernamental, que sólo es capaz de producir mártires ácratas y un incremento de su popularidad. El verdadero remedio contra el anarquismo consistirá en difundir unos métodos de enseñanza racionales, ya que «la crítica destruye sus fundamentos» y reducir el analfabetismo, puesto que «el anarquismo no existe o no es temible en los países donde más se difunde la cultura», y está comprobado que «disminuye la importancia del anarquismo a medida de los analfabetos». De acuerdo con Unamuno, Maeztu propone una campaña cultural frente a una apocalíptica anarquía: «Sólo un ambiente de general cultura puede acabar con las propagandas separatista y libertaria, sólo la cultura podrá salvarnos!» (1901f).

Maeztu, sensible a la agitación anarquista, y con un buen conocimiento del movimiento obrero en España, fue corresponsal de diversos paros y huelgas: muestra de su dinámico periodismo sobre el terreno fue la serie de artículos que publicó en el Diario Universal sobre una huelga en Reus (del 11 de enero al 11 de febrero de 1903), reportaje en el que analizó detenidamente sus causas, las reacciones de las dos partes en conflicto, obreros y patronos, y los resultados del mismo. Análogo interés social tienen las posteriores entregas sobre el campo andaluz (1903b), crónica autobiográfica y reportaje del viaje, donde incluye, al modo de un análisis sociológico, entrevistas y opiniones de diversos afectados, además de numerosos datos y cifras económicas. Denuncia el retraso tecnológico y la mala explotación de las fincas, para acabar defendiendo a los capitalistas que, de modo emprendedor, reinvierten sus beneficios y así enriquecen también su comunidad.

\section{Maeztu y Nietzsche: una ética, un estilo y una máscara textual}

Maeztu comparte con sus compañeros de la joven literatura, además de su afán iconoclasta contra todo lo establecido, jerarquías o valores, y el deseo de conquistar el campo literario, su aprecio por Schopenhauer, Stirner o Nietzsche, de modo destacado este último (Sobejano 1967), pensadores individualistas de gran presencia en el ambiente intelectual y creativo del fin de siglo: 
«Max Stirner, Schopenhauer, Etiévant, Malthus, y sobre todo Federico Nietzsche dirigiendo sus lógicas hacia su instinto, nos han señalado el derrotero» (Maeztu, 1997: 210). Al último lo califica como su ídolo, y proclama el triunfo de la moral nietzscheana, creador de un futuro despotismo de la belleza, la inteligencia y la voluntad (1899o).

Maeztu aprovechó de Nietzsche, además de su prestigio e impacto intelectual y revolucionario, diversos aspectos de su teoría ética y estética, quizá más de la primera que de la segunda; su impugnación del horizonte trascendente platónico-cristiano, tanto racional como espiritual; su llamada hacia un renovado vitalismo -el ideal de la juventud nueva ha de ser el «de la vida misma», el de «la vida por la vida» (Maeztu, 1997: 205)-, y su creencia en el venidero superhombre, el hombre de acción y de presa, ambicioso y amoral. Todo ello se adapta bien a su visión pragmática, antihistórica, antitradicional, antiestatal y anticlerical de la nueva España, a su labor de acoso y derribo del sistema social, político y moral de la Restauración, y a su ideal de regeneración económica, encarnado en el capitalista negociante e industrializador, al margen de política y gobiernos.

También es deudor de Nietzsche en su construcción de un personaje textual brillante y contradictorio, siempre polémico y de gran energía expresiva: paradójicamente, al lado de sus análisis socioeconómicos, su prosa está henchida de frases y lemas del filósofo alemán. El joven Maeztu combina el frío análisis racional de los hechos con una apasionada exaltación nietzscheana, y no deja de empuñar el látigo, la soberbia, las paradojas, los símbolos y la máscara de un Zaratustra hispano, como era conocido entre los jóvenes escritores de su tiempo. Estos elementos a veces se funden con el empleo, como vehículo retórico, de algunos rasgos, imágenes y metáforas empleadas por los modernistas (por ejemplo, las visiones crepusculares urbanas, de tradición baudelairiana y simbolista ${ }^{1}$ ). La vehemencia expresiva de Maeztu se concreta en frecuentes repeticiones, anáforas y paralelismos que enfatizan y subrayan las ideas que plasma en sus escritos. Su modelo de una escritura viva y orgánica, al margen por completo de retóricas castizas, lo expuso en su autobiográfica «Juventud menguante»:

1. Vid. Maeztu, 1997, 127: «La lectura del discurso me causó una impresión profundísima. Era en un crepúsculo de la tarde; leíalo en el balcón y los contados transeúntes que pasaban, por debajo de mí, llevaban impresa en los rostros la melancolía desesperada del acabamiento de un día más. Frente a los colores espléndidos y suaves del crepúsculo, sentíase un inefable decaimiento, como si toda la luz fuera a apagarse para una noche eterna. Las caricias del aromado viento sugerían la imagen de un moribundo gigantesco, como si al agonizar la tierra de una enfermedad voluptuosa y extraña, placentera e incurable, exhalase un suspiro de enervador perfume». 
a ratos, uno o dos ratos cada mes, todo el artículo se anima con un fuego interno, plenitud cerebral, embriaguez ideológica, que reduce a unidad suprema palabras y conceptos, como si los huesos y la médula, los músculos y la sangre, se incorporaran al papel, y entonces sea cualquiera la índole del escrito -cuento, crítica, artículo político, lucubración metafísica, estudio social, análisis económico-, vibra con vibraciones de calor y de luz, despierta curiosidades aletargadas, enciende pasiones y ternuras y provoca, indefectiblemente, ardorosas polémicas, con adhesiones entusiastas y con protestas llenas de odio (Maeztu, 1904).

Sin embargo, quizá por influjo de Unamuno, Maeztu (1902) se despoja de la radical y apasionada máscara de Zaratustra: una vez que ha alcanzado cierto prestigio y tiene a su disposición las páginas de los mejores periódicos, ya no la necesita. Por eso, en un nuevo rasgo de egocentrismo exhibicionista, disfruta escenificando las exequias de su identidad y renaciendo con otra de estilo más sobrio, que se adapte mejor a la realidad española, en una fábula narrada en tercera persona: «Cuando volvió a escribir su tono era distinto. La prosa, antes forzada se hizo honesta; cambió los colorines por los tonos grisáceos; abandonó afeites y pinturas, como ornamentos pecaminosos; trocó el dios fuerza por la hermana humanidad; los amoríos de la paradoja y la postura por los amores de la delicadeza y la bondad; su patriotismo ruinoso y agresivo se hizo amable, resignado, casi místico; el cantor de la violencia se convirtió en amigo de la piedad» (Maeztu, 1904). No por ello pierde su apasionamiento ni su vehemencia.

Los rasgos vitales y formales del poderoso estilo de Maeztu, periodístico pero cuidado y literario, establecen un vaso comunicante con sus escritos puramente creativos: amén de algunos poemas de inspiración baudelairiana, Maeztu escribe en el fin de siglo relatos de ficción similares a los del Azorín o el Baroja de aquellos años, y con una temática análoga: cuentos de propaganda social, cuyos motivos eran las huelgas, el hambre y la vida de los obreros (aparte de algunos componentes de erotismo), ejemplificación de las tesis revolucionarias y socialistas de su pensamiento (Maeztu, 2000).

\section{Maeztu, crítico literario y artístico. Las polémicas con el modernismo}

Maeztu también practicó la crítica literaria; junto al periodismo, el arte es un elemento aprovechable para su campaña de regeneración nacional: «Todo es cuestión de concertar nuestras fuerzas en sintética vida de arte y de trabajo» (Maeztu, 1901). Para él, como para Tolstoi en ¿Qué es el arte?, la literatura debe ser un revulsivo social, un elemento vivo, capaz de expresar la lucha por la vida (1899j). De todos los géneros, el teatro era el más poderoso instrumento de propaganda, puesto que llegaba a gran cantidad de espectadores, 
incluso a los que nunca leían. Por eso las candilejas podían colaborar en la regeneración de la patria. Así, las obras preferidas de Maeztu, que desdeña el teatro convencional de su tiempo, son las de denuncia social, como Juan José de Dicenta, Electra y Mariucha de Pérez Galdós, que exponen los conflictos entre las clases explotadoras y ociosas, burguesía y clero, por un lado, y el nuevo trabajador de la naciente España, por el otro ${ }^{2}$.

En «Mi programa», Maeztu expone teóricamente su concepción de la literatura y de la crítica literaria. Su punto de partida nuevamente es el vitalismo de Nietszche: «ver la verdad por la óptica del artista, pero el arte por la óptica de la vida», puesto que «antes de artista y después de artista el escritor ha de ser hombre, y hombre de su tiempo». La razón para ello es que «la vida hace al artista... más artista» (concepción similar a la de Antonio Machado). Esta insistencia denota una prevención contra la idea de «el arte por el arte», que Maeztu rechaza por artificial, decadente y alejada de la realidad social e histórica de España. Sin embargo, la creencia de que la escritura debía de reflejar la vida y la propia personalidad, de que «el estilo es el hombre» (Maeztu, 1904b), parafraseando a Buffon, no era exclusiva de Maeztu, sino que estaba ampliamente extendida y aceptada en el fin de siglo, desde Pío Baroja (1899), quien declaraba que el estilo modernista es deudor de «una individualidad poderosa, que es la única que puede producir materia artística», a Manuel Machado (1902): «Detrás de un libro hay un artista, un hombre, una personalidad, o no hay nada».

En cuanto a la crítica literaria, las cuestiones que le interesan a Maeztu tras la lectura de una obra son «¿Qué me deja? ¿En qué se han esclarecido mis nociones del mundo? ¿En qué ha aumentado mi sensibilidad ante lo bello? ¿Ha crecido mi fuerza? ¿Me ha señalado peligros nuevos? ¿Soy más apto para el combate de la vida?» (Maeztu, 1901). Estas preguntas encauzarían sus comentarios de libros en las publicaciones en que se encargó de esta labor, desde El País a Vida Nueva y a Electra.

Con estas ideas, Maeztu terció polémicamente en la reivindicación del Quijote como guía espiritual de los nuevos escritores, proceso que culminó con la celebración en 1905 del tricentenario de la primera parte de El ingenioso hidalgo y los conocidos ensayos cervantinos de Unamuno o Azorín, entre otros. Frente a sus compañeros, en una serie de artículos dialogados, Maeztu denostó la obra por considerarla un libro que, aunque genial, muestra

2. A Galdós lo admira sin reservas; sin embargo, de Dicenta escribe que «colocado, por un capricho de su genial instinto, en el punto donde acaba el concepto calderoniano del amor y de la honra y comienzan las positivas luchas de estos días, no atina con el modo de desprenderse de la corcova romántica» (Maeztu, 1899b). 
la decadencia de un pueblo y de un imperio, escrito por un fracasado en el momento en que España perdía el tren de la historia, de la reforma y del renacimiento (1901c). Los ensueños de su protagonista nada podían aportar a la nueva España, y sólo interesaban a los literatos y eruditos: «no pretendamos convertir en libro vital de España ese libro de abatimiento y de amargura» (Maeztu, 1903c; vid. Alarcón, 2006).

Igual de polémico es en su consideración de la nueva literatura de su tiempo, a la que, sin embargo, pertenece de pleno derecho. Las letras de la Restauración también estaban hundidas; en España no había literatura, puesto que «una vez realizado el desarrollo económico de un pueblo, es inminente la era de su apogeo artístico», pero todavía había que realizar lo primero. Cuando se alcanza dicho objetivo, «la literatura nace a su tiempo, desempeña una misión completa y corona una nacionalidad, añadiendo a la rudeza de la vida práctica los encantos fugitivos, pero inefables del ensueño». Según esta consideración, la literatura es el descanso de los pueblos trabajadores, no de los ociosos. Por consiguiente, en España «no hay literatura porque primeramente necesitamos hacer patria, y las patrias no se hacen con la pluma, sino con el arado, aunque luego la pluma las exorne». Además, ¿qué literatura necesitaría esta nación atrasada?: «una que fuera acción, látigo e impulso, que se identificara con los modernos combates económicos, que barriera la grafomanía que en Madrid se estila, inmóvil como las estepas castellanas, odiosa como un rezo, huera como un discurso democrático, inútil como las aguas de esos ríos que en el mar se pierden sin fecundar las tierras...» (1899h).

En síntesis, Maeztu pide una literatura viva, renovadora, dinámica y moderna, adaptada en su forma y contenido a las necesidades y a los problemas contemporáneos. Este ideal de escritura supondría la ruptura del canon de su tiempo: «esa literatura que fuera a la vez lucha, literatura de las calles rectas y de la máquina, de la Bolsa y de las empresas por acciones, frente a la literatura crepuscular de las añoranzas y de los ensueños... ¿no sería esencialmente antiliteraria?» (1899h). Con este razonamiento, parece adelantar las bases de una cuestión que volvería a plantearse años después, con la irrupción iconoclasta de las vanguardias.

Maeztu rechaza el anquilosamiento de la crítica tradicional y la gente vieja ante el surgimiento de una nueva estética: «¡Y ahí está esa literatura, a la vez española y exótica, que nos avergüenza con sus bríos juveniles, escrita por los americanos en un lenguaje apenas inteligible para nosotros, y por los españoles en dialectos e idiomas que creíamos olvidados literariamente para siempre!». El naciente modernismo comienza a sentar las bases de un cambio profundo y renovador. De hecho, frente a las burlas de Leopoldo Alas y la 
castiza literatura defendida desde las páginas de Madrid Cómico, Maeztu defiende a Benavente y a los jóvenes escritores como un valor superior: «Aceptemos las manos liliales, las torres ebúrneas y demás letanías de nuestros seudodecadentes, naturistas y estetas, como un anhelo indefinido, como un vago vislumbre de otra literatura, como un preludio cuatrocentista de un renacimiento» (Maeztu, 1899q).

También escribe positivamente de otros autores modernos: de Valle-Inclán, al que respeta como «modelo y ejemplo de energía» (1899r), cualidad compartida por el propio Maeztu, quien seguramente vería a Valle como un hermano de sangre virado hacia la estética, puesto que ambos comparten una temprana experiencia americana, la necesidad de un auditorio que los escuchara sin rechistar (desde el periódico o desde la tertulia) y, sobre todo, la construcción autobiográfica y exhibicionista de su propio personaje (hacerse una cabeza). Sus elogios alcanzan a Blasco Ibáñez (1900b) y a Baroja (1901d), amén de a Unamuno, citado en numerosos artículos. En el Rubén Darío de Azul... y Prosas profanas reconoce a «un talento de primera fila» con «un arte personal, rebuscado y sabio», en quien sin embargo agudamente advierte «un hombre de carne y hueso que aún no ha escrito» (1899e). Quizá tenga razón, a la vista del Darío de Cantos de vida y esperanza.

Sin embargo, la situación cambia en poco tiempo. Maeztu percibe que el modernismo está ocupando cada vez más espacio en el campo literario y social, y sus intereses y objetivos son, en general, distintos a los que propone el nietzscheano periodista. Los jóvenes estetas ya no son una promesa, sino una realidad que puede hacer sombra al impetuoso Zaratustra hispano. Paulatinamente serán aceptados por el lector burgués y, desactivado su primer ímpetu iconoclasta, acabarán representando sus valores. Adelantándose a este momento, Maeztu descubre el juego hipócrita de los jóvenes escritores, que no se ocupan en sus textos de la realidad social y económica aunque dependan de ella: «los literatos hoy de moda -hermanos intelectuales del megaterio- que se hacen ascos de la moneda y luego la imploran a dos manos» (Maeztu, 1997: 222) -cruda imagen del artista inmerso en el mercado- y, por tanto, critica a los modernistas como un estorbo para sus ideales de regeneración social. La «epopeya nueva» es la de «la industrialización del suelo», pero «sólo un escritor, Pérez Galdós, ha desentrañado del burbujeo de los gérmenes la España capitalista que se nos echa encima», porque "¿cómo van a cantar esos [nuevos] literatos la nueva España, si ésta es la máquina, la dinamo, la empresa por acciones, el combate económico, sañudo e implacable, y las ideas que de este mundo tienen son reflejas, librescas, no personales ni directas?» (Maeztu, 1997: 199-200). 
En «Mi programa», Maeztu localiza la nueva España «en esas industrias que han transformado rápidamente el aspecto de la estática Castilla. Y la presiento, ¡oh mineros, mercadores y bolsistas que jamás enfocasteis la mirada hacia una creación del arte!, la presiento..., en nuestra juventud intelectual»; pero, a continuación, arremete con la parte de esa juventud refractaria a sus intereses:

Por ley del contraste los escritores jóvenes se encastillan en su torre de marfil. Uno de los más jóvenes, y a la vez de los más estimables, asentaba el principio de que la humanidad no merecía ningún idealismo. Aunque el pensamiento no era nuevo, me enfurecí leyéndolo. ¿Y quién, entonces, lo merece? ... ¿Tu impotencia para sentir? ¿Tu miopía para ver?... Guarda, decadente, no empuñe el látigo y descubra el raquitismo de tu cuerpo... La vergüenza sólo puede excusarla el heroísmo de callar (Maeztu, 1901).

Al poco tiempo, Manuel Machado, implicado junto a Maeztu en la dirección de Electra y quizá aludido en el artículo anterior, le contesta (lo que la crítica no había advertido) haciendo una evidente caricatura del exacerbado escritor, de su estilo nietzscheano y de sus ideas regeneracionistas, con el que establece un ficticio diálogo:

Otra variedad del super-López, que concierne al arte y principalmente a la literatura, es un joven Zaratustra, que habla en versículos y maneja en el vacío un formidable látigo. Este clama contra el turrieburnismo " $i$ Hay que sacar a los jóvenes poetas de su torre de marfil, arrojarlos enmedio de la vida para que la canten y sublimen en sus versos. Nada de aislamientos ni de idealismos. Hay que cantar el obrero y la obra, la mina y los mineros, y lo mejor no cantar y bajar a la mina. El progreso, las máquinas, el comercio, los viajantes de comercio...! ! .

-Enhorabuena. Que hagan eso los que quieran hacerlo; pero deje a los demás que sean como son, único medio de ser artistas; usted, hombre fuerte, vaya a cavar enhorabuena (con este tengo confianza) o baje a la mina o invente una máquina. Pero ya sabe usted que el arte puede estar ahí en eso y en todo lo contrario. Sobre todo en esas torres de marfil que usted quiere derribar. Además, un poeta de alientos positivos y enamorado de la vida en nuestra pobre España de hoy, me parecería tan falso, tan falso.

Este no me citó filósofos, sino se fue restallando su látigo y llamándome «venenoso» porque le dije que al cabo todo podía ser lo mejor (Machado, 1901b; para el «látigo», vid. además Maeztu, 1898).

A los tres días de aparecer este artículo, Maeztu contraataca arremetiendo sarcásticamente contra «el arte por el arte», al que considera poesía estéril, sin pensamiento: «Es el modernismo como ciertas mujeres; bueno jugar con ellas, ipero no enamorarse!», para acabar con una alusión a la hiperestesia de Juan Ramón Jiménez, que «ha dado con sus huesos, a los veinte años de su edad, en una casa de alienados...», y una pulla indirecta a Manuel Machado: 
«No imitéis a los que han buscado el secreto de París, 'la hora cárdena', en las copas de ajenjo...» (Maeztu, 1901e): «la hora cárdena» era sintagma repetido en el poema de Machado «Mariposa negra», publicado en el mismo número de Electra en que Maeztu escribió «Mi programa».

Maeztu rechaza la posibilidad de un arte puramente estético, sin otro objetivo que sí mismo. Sus argumentos de nuevo los fundamenta en las ideas de Nietzsche: «El arte es el gran estimulante de la vida: ¿cómo creerlo sin finalidad, sin objetivo, cómo llamarlo el arte por el arte?» (1903a). Además, a Maeztu le preocupa que a él mismo lo confundan con uno de ellos, puesto que en España se aplica el adjetivo «modernista» a todos los jóvenes iconoclastas y contestatarios lanzados a la conquista del campo literario, al margen de sus méritos y de sus intenciones; es la misma crítica que hacía a dicha denominación Manuel Machado, quien no la aceptaba por estar vacía de contenido (vid. Machado 1901a, 1903 y 1907, textos analizados en Alarcón Sierra, 2000). A Maeztu, todo lo que no fuera preocuparse de las realidades políticas y económicas de su tiempo, incluso en la literatura, le parecía un desgaste de energía inútil y una pérdida de tiempo3.

Maeztu también fue un persistente crítico de arte, dedicación no extraña si, al interés del vitoriano por todos los aspectos de la cultura española, unimos el hecho de que su hermano Gustavo era pintor. En las primeras décadas del siglo -sobre todo a partir de 1903-se ocupó preferentemente de la pintura española en diversas publicaciones como Diario Universal, El Pueblo Vasco o España. Además de otros pintores vascos, como Juan de Echevarría, alabó sobre todo (al igual que Unamuno y Azorín) la pintura de Ignacio Zuloaga, al que calificó de luminista y pintor de ideales, destacando su combinación de la tradición de Velázquez, El Greco y Goya, iconos del espíritu finisecular, con las técnicas modernas. Sin embargo, el ideal pictórico de Zuloaga nunca fue el moderno e industrial País Vasco, sino esa Castilla mesetaria, negra, atemporal y abandonada que con tanto ímpetu quería transformar Maeztu. Quizá viera en la pintura de Zuloaga un componente de crítica social a las lacras nacionales que tan obsesivamente retrataba, de los curas a los toros. El interés de Maeztu por la pintura se extenderá a la década siguiente, en la que dedicó interesantes artículos al cubismo, el futurismo y el expresionismo. A su informada visión de las vanguardias artísticas deberá mucho La deshumanización del arte de Ortega y Gasset (vid. Bernal Muñoz, 1998, Fox, 1988, Flores Pavía, 2000).

3. En otros artículos critica a Benavente, Manuel Reina, Gregorio Martínez Sierra, Icaza o Eduardo Marquina: Maeztu, 1899k, 1899l, 1900ª y 1900c, respectivamente. 


\section{Conclusiones}

En la encrucijada de socialismo y capitalismo encontraba Maeztu la solución al atraso español. Pero, puesto que los verdaderos colectivos burgués y obrero del país no eran capaces de llevar a cabo la transformación, esta la confiaba, en un acto de fe, a las poderosas «individualidades sensatas y enérgicas, perspicaces y estimuladas por una ambición noble» que, al margen de gobierno y Estado, debían surgir en el futuro: «en ellas depositamos nuestra esperanza de mejores días». Maeztu se adjudica el papel de profeta, guía y faro que ilumina el camino desde su tribuna periodística: «Esos hombres, que hoy son pocos y están desparramados, mañana serán más, se organizarán, agruparán en torno suyo a la nación trabajadora; de ellos saldrá otra España más noble, más bella, más rica y más grande» (Maeztu, 1997: 151).

La misión que Maeztu reservaba a sus compañeros de letras era la de emplear su poder de convicción en consolar a los afligidos colectivos que dependían del presupuesto, primer objetivo a batir: «Cumple a los escritores, en esta gran transformación, un papel importante, ya que no de primer orden. Ellos han de dulcificar la inevitable caída de las no adineradas clases medias» (Maeztu, 1997: 221). Y el final de Hacia otra España, contrafigura de «La canción del oro» del rubendariano Azul..., era la nueva oración que Maeztu proponía a sus creyentes: «Cuando sobre la espada del militar, sobre la cruz del religioso y sobre la balanza del juez, ha triunfado el dinero es porque entraña una grandeza más intensa que ninguno de esos otros artefactos. ¡Torpe quien no la vea! Cantemos al oro; el oro vil transformará la amarillenta y seca faz de nuestro suelo en juvenil semblante: ¡el oro vil irá haciendo la otra España!» (Maeztu, 1997: 222-223).

De este modo, la suma de contradicciones en sus análisis sociológicos, aparentemente objetivos e impecables, llevaba al anticlerical Maeztu a caer en la fe de un nuevo irracionalismo donde, si se me permite el juego de correspondencias, el Espiritu Santo no era otro que el verbo inspirador de Nietzsche, junto con algunos otros pensadores ya citados; el Dios Padre, salvador y redentor, el dinero; su Hijo encarnado en la tierra, el hombre de negocios del futuro, el superhombre venidero; el propio Maeztu, su profeta y su Moisés, que difundiría a través de la prensa su mensaje y las nuevas tablas de la ley; mientras que a los escritores jóvenes, todavía díscolos e incrédulos, les reservaba la tarea de formar el cuerpo eclesial que consolara desde la prensa a su feligresía. La evolución posterior de Maeztu no iba sino a acrecentar este «sentido reverencial del dinero», a poner cada vez más de manifiesto los aspectos en el fondo autoritarios y dogmáticos de esta nueva concepción, y a convertir su crítica al Estado y a la Restauración en la defensa de una monarquía militar 
antiparlamentaria. Finalmente, la vehemencia de su fe, tras el hundimiento de su primer ideal renovador, se pondría al servicio, con el mismo ímpetu, del cristianismo más integrista.

Sin embargo, al Maeztu finisecular, todavía lejos de su posterior evolución, no se le pueden negar numerosos méritos: la tentativa de situar a su nación en el mismo nivel de desarrollo y progreso que los países europeos de su entorno; el ocuparse aguda y críticamente de todos los aspectos de la vida española; el practicar un nuevo periodismo, moderno, riguroso e independiente, capaz de denunciar cualquier lacra, viniera de donde viniera; su insobornable honestidad intelectual; y finalmente, y quizá a su pesar, el adelantar en sus contradicciones las tensiones internas -políticas, sociales, económicas y culturales- que iban a estallar en Occidente a lo largo de todo el siglo XX.

\section{Bibliografía citada}

Abellán, José Luis, «Ramiro de Maeztu o la voluntad de poder», Sociología del 98, Barcelona, Península, 1973, pp. 141-160.

AlarCón Sierra, Rafael, Manuel Machado, Impresiones. El modernismo. (Artículos, crónicas y reseñas, 1899-1909), Valencia, Pre-Textos, 2000.

— «El Quijote modernista (Unamuno, Maeztu, Azorín)», en R. Alarcón Sierra (ed.), «No ha mucho tiempo que vivía»... De 2005 a Don Quijote, Jaén, Universidad de Jaén, 2006, pp. 345-389.

Alonso, Cecilio, «Confluencias generacionales. Algunas notas sobre prensa diaria y literatura entre la Restauración y la Regencia». En L. Romero Tobar, ed. El camino hacia el 98 (Los escritores de la Restauración y la crisis del fin de siglo), Madrid, Fundación Duques de Soria/Visor, 1998.

BAROJA, Pío, «A la juventud intelectual», Revista Nueva, 1 (1899), en Obras completas, Madrid, Biblioteca Nueva, 1951, VIII, p. 847.

Baudelaire, Charles, Petits poèmes en prose. Ed. crítica de R. Kopp, París, José Corti, 1969.

Benjamin, Walter, Discursos interrumpidos, Madrid, Taurus, 1973.

Bernal Muñoz, José Luis (comisario), Arte y literatura en la Edad de Plata. La mirada del 98, Madrid, Ministerio de Educación y Cultura, 1998.

Blanco Aguinaga, Carlos, «La otra España de Maeztu». Juventud del 98, Barcelona, Crítica, 1970, pp. 175-193.

Blas Guerrero, Andrés de, La ambigüedad nacionalista de Ramiro de Maeztu. Barcelona, Institut de Ciències Politiques i Socials, 1993.

Darío, Rubén, Obras completas, II. Semblanzas, Madrid, Afrodisio Aguado, 1950. Fernández URbina, José Miguel, La aventura intelectual de Ramiro de Maeztu. Vitoria, Diputación Foral de Álava, Departamento de Cultura, 1990. 
Flores PaVía, María José, «Del modernismo al arte puro: Ramiro de Maeztu y Ortega y Gasset en las polémicas literarias del primer cuarto del siglo XX», en P. L. Crovetto y L. de Llera (eds.), Autobiografías y polémicas, Génova, Università degli Studi di Genova, 2000, pp. 135-156.

Fox, E. Inman, «Un bibliografía anotada del periodismo del joven Ramiro de Maeztu y Whitney (1897-1904). Cuadernos Hispanoamericanos, 291 (1974), pp. 528-581.

- Ideología y política en las letras de fin de siglo (1898), Madrid, Espasa-Calpe, 1988.

Gómez CARrillo, Enrique, «La crónica parisiense», El Liberal (3 de febrero de 1902).

GÓmEZ DE BAqUERO, Eduardo, Letras e ideas. Barcelona, Imprenta de Henrich y Cía- Editores, 1905.

MACHADO, Manuel, «El modernismo y la ropa vieja», Juventud, I, 1 (1 de octubre de 1901a).

— «El super-López», Don Quijote (11 de octubre de 1901b), p. 4.

- «De literatura. RIMAS.-Colección de poesías por Juan R. Jiménez.-Madrid, 1902», El País (3 de abril de 1902).

— «Eso del modernismo...», El País (20 de marzo de 1903).

— «El modernismo según Manuel Machado», El Nuevo Mercurio, 5 (mayo de 1907).

— «En, con, por, sin, sobre... la crónica», La Libertad (21 de marzo de 1923), p. 1.

MAEZTU, Ramiro de, «¿Qué se debe hacer de Cuba? Cuatro palabras con sentido común», Germinal (6 de agosto de 1897a)

— «La dignidad obrera en el taller madrileño», Germinal (24 de septiembre de 1897b).

— «Ideal nuevo», El Progreso (6 de febrero de 1898).

- «El dinero frente a la iglesia», Vida Nueva (23 de febrero de 1899a).

— «Hacia otra España (fragmento)», La Vida Literaria, 9 (4 de marzo de 1899b), p. 151.

— «Los secretos de la crisis», Revista Nueva, 3 (5 de marzo de 1899c).

— «Los secretos de la crisis (conclusión)», Revista Nueva, 4 (15 de marzo de 1899d).

— «El pensamiento de América», Vida Nueva, 1 (abril de 1899e).

— «El dinero frente al Estado», Vida Nueva, (9 de abril de 1899f)

— «La cuestión hidraúlica», Las Noticias, Barcelona (15 de abril de 1899g).

- «En la charca. Allá van los hechos», Revista Nueva, I, 7 (15 de abril de 1899h), p. 314.

— «Las minas del Bilbao», Vida Nueva (30 de abril de 1899i).

— «Marx en la literatura», El Socialista, (1 de mayo de 1899j).

Anales, 26, 2014, pp. 11-41 
- «Un rato a libros», Vida Nueva, 50 (21 de mayo de 1899k).

- «Un poeta», Vida Nueva, 50 (21 de mayo de 1899l).

— «La moral que muere y la que nace», Revista Nueva 12 (5 de junio de 189911).

— «Una ciudad comida por el clero», Vida Nueva (9 julio de 1899m).

— «La Nación contra el Estado», Revista Nueva, (25 de julio de 1899n).

— «Cataluña y las Vascongadas ante España», Las Noticias (6 agosto de 1899ñ).

— «Nietzche y Maquiavelo», Vida Nueva (13 de agosto de 1899o).

— «Solidaridad española», I, Las Noticias (22 de septiembre de 1899p).

— «Clarín, Madrid Cómico and C $C^{\circ}$ Limited», Revista Nueva, II, 25 (14 de octubre de 1899 q), pp. 52-53.

— «Valle-Inclán», Las Noticias (3 de diciembre de 1899r).

— «Un poeta joven», Vida Nueva, 86 (28 de enero de 1900a).

— «Blasco Ibáñez», El País (3 de febrero de 1900b).

— «La gente que viene», Las Noticias (1 de febrero de 1900c).

— «La liga de Manchester y la Unión Nacional», Revista Política y Parlamentaria (mayo de 1900d).

— «El público. Desde dentro», El País (31 de enero de 1901a).

— «Mi programa», Electra, 1 (16 de marzo de 1901b).

— «El libro de los viejos», La Correspondencia de España (12 de mayo de 1901c).

— «Pío Baroja», Madrid (4 de junio de 1901d).

- «Poesía modernista» en Los Lunes de El Imparcial (14 de octubre de 1901e).

- «El ideal anarquista en España», El Imparcial (28 de noviembre, 6, 16 y 24 de diciembre de 1901f).

- «Cómo muere un Superhombre», La Correspondencia de España (19 de enero de 1902).

— «Todos modernistas», Diario Universal (15 de marzo de 1903a).

— «Un viaje a Jerez. El pantano de Guadalcacín» y «Después del viaje», Diario Universal (10, 17, 19 y 23 de abril de 1903b).

— «Ante las fiestas del Quijote», Alma Española, (13 de diciembre de 1903c).

- «Autobiografías. Juventud Menguante. Ramiro de Maeztu», Alma Española, 12 (24 de enero de 1904a), pp. 14-15.

— «Un libro de Giner», España, (28 de marzo de 1904b).

- Los intelectuales y un epílogo para estudiantes. Ed. V. Marrero, Madrid, Rialp, 1966.

- Artículos desconocidos. 1897-1904. Ed. E. Inman Fox. Madrid, Castalia, 1977.

- Hacia otra España. Intr. J. Varela. Madrid, Biblioteca Nueva, 1997.

- Obra literaria olvidada. Ed. Emilio Palacios Fernández, Madrid, Biblioteca Nueva, 2000.

MAINAR, Rafael, El arte del periodista. Barcelona, José Gallach Editor, 1906.

PALACIOS FERNÁNDEZ, Emilio, Ramiro de Maeztu. La labor literaria de un periodista (1897-1910), Vitoria, Diputación Foral de Álava, 1983. 
SANTERVÁs, Rafael, La etapa inglesa de Ramiro de Maeztu, Madrid, Universidad Complutense, 1987.

SiMmEL, Georg, El individuo y la libertad. Ensayos de crítica de la cultura, Barcelona, Península, 1986.

SobejAno, Gonzalo, Nietzsche en España, Madrid, Gredos, 1967.

Unamuno, Miguel de, Obras completas, Madrid, Afrodisio Aguado, 1958.

Villacañas, José Luis, Ramiro de Maeztu y el ideal de la burguesía en España, Madrid, Espasa, 1999.

Zaratiegui, Jesús M., «El periodismo económico de Ramiro de Maeztu», en L. Perdices de Blas y M. Santos Redondo (coord.), Economía y literatura, Madrid, Ecobook / Instituto de España / Consejo Económico y Social / Comunidad de Madrid, 2006, pp. 433-490.

Fecha de recepción: 05/04/2014

Fecha de aceptación: 17/09/2014

Anales, 26, 2014, pp. 11-41 